\title{
Preparedness of Coastal Community Purworejo Against Megatrhtust Threat
}

\author{
Abdul Latif RF, Chatarina Muryani, Yasin Yusup
}

Sebelas Maret University

abdul.latif.rf@student.uns.ac.id

Article History

accepted 31/08/2020

approved 22/09/2020

published 28/10/2020

\begin{abstract}
Since the tsunami in 2004 in the Indian Ocean, studies of the megatrust tsunami have been increasing. One of the reasons is because the megatrust tsunami can cause large numbers of casualties, as has happened in Aceh and Mentawai (Indonesia). The threat of a megatrust tsunami now stretches along the coastline of the southern island of Java. Communities who are in the southern part of Java, ideally have the ability to be prepared to face a tsunami disaster. Therefore, an assessment of community preparedness in the face of a tsunami in Purworejo Regency is an urgency, because Purworejo is one of the regencies directly adjacent to the ocean in the south of Java Island. This study uses a combination of questionnaires, interviews, observation and documentation to obtain data. This study provides information on the classification of villages along the coast of Purworejo in relation to the level of preparedness to face the threat of a tsunami disaster. The result is that from 16 villages 2 of them are of high status, 2 are low and the rest are moderate.
\end{abstract}

Keywords: Megathrust Tsunami, Preparedness, Purworejo

\begin{abstract}
Abstrak
Sejak terjadinya tsunami pada tahun 2004 yang berada di Samudra Hindia, kajian mengenai tsunami megatrust semakin meningkat. Salah satu alasannya yaitu karena tsunami megatrust dapat menimbulkan korban jiwa dalam kuantitas yang besar, seperti yang pernah terjadi di Aceh dan Mentawai (Indonesia). Ancaman tsunami megatrust kini membentang di sepanjang garis pantai Pulau Jawa sebelah selatan. Masyarakat yang berada di bagian selatan Jawa, idealnya memiliki kemampuan kesiapsiagaan untuk menghadapi bencana tsunami. Maka dari itu, pengkajian terhadap kesiapsiagaan masyarakat dalam menghadapi tsunami di Kabupaten Purworejo menjadi suatu urgensi, karena Purworejo salah satu kabupaten yang berbatasan langsung samudera di selatan Pulau Jawa. Penelitian ini menggunakan kombinasi kuisioner, wawancara, observasi dan dokumentasi untuk memperoleh data. Studi ini memberi informasi klasifikasi desa di sepanjang pesisir Purworejo berkaitan dengan tingkat kesiapsiagaan menghadapi ancaman bencana tsunami. Hasilnya yaitu dari 16 desa 2 diantaranya berstatus tinggi, 2 rendah dan selebihnya sedang.
\end{abstract}

Kata kunci : Tsunami Megatrust, Kesiapsiagaan, Purworejo

Social, Humanities, and Education Studies (SHEs): Conference Series https://jurnal.uns.ac.id/shes 


\section{PENDAHULUAN}

Indonesia adalah negara kepulauan terbesar di dunia yang terdiri dari lebih dari 17.000 pulau yang tersebar lebih dari 5.000 kilometer dari barat ke timur (Bahagia et al., 2013). Sebagai negara dengan jumlah pulau terbesar di dunia, Indonesia memiliki banyak pantai dan pegunungan. Hamparan keindahan tersebut mampu menyamarkan fakta menakutkan bahwa Indonesia terletak di atas garis seismik "Cincin Api" yang membentang di sekitar Pasifik dari Australia tenggara hingga Amerika Barat Daya seperti ditunjukkan pada Gambar 1 (Pambudi, 2018). Artinya, Indonesia berada di pertemuan lempeng (subduksi) yang mengakibatkan adanya tekanan endogen yang kuat. Karena tekanan kuat yang dihasilkan dari dalam bumi, hal tersebut membuat Indonesia terdapat banyak pegunungan dan gunung api. Selain memiliki ancaman erupsi gunung berapi, Indonesia juga memiliki ancaman tsunami. Faktanya, Indonesia memiliki belasan ribu pulau dan tentunya memiliki garis pantai yang Panjang.

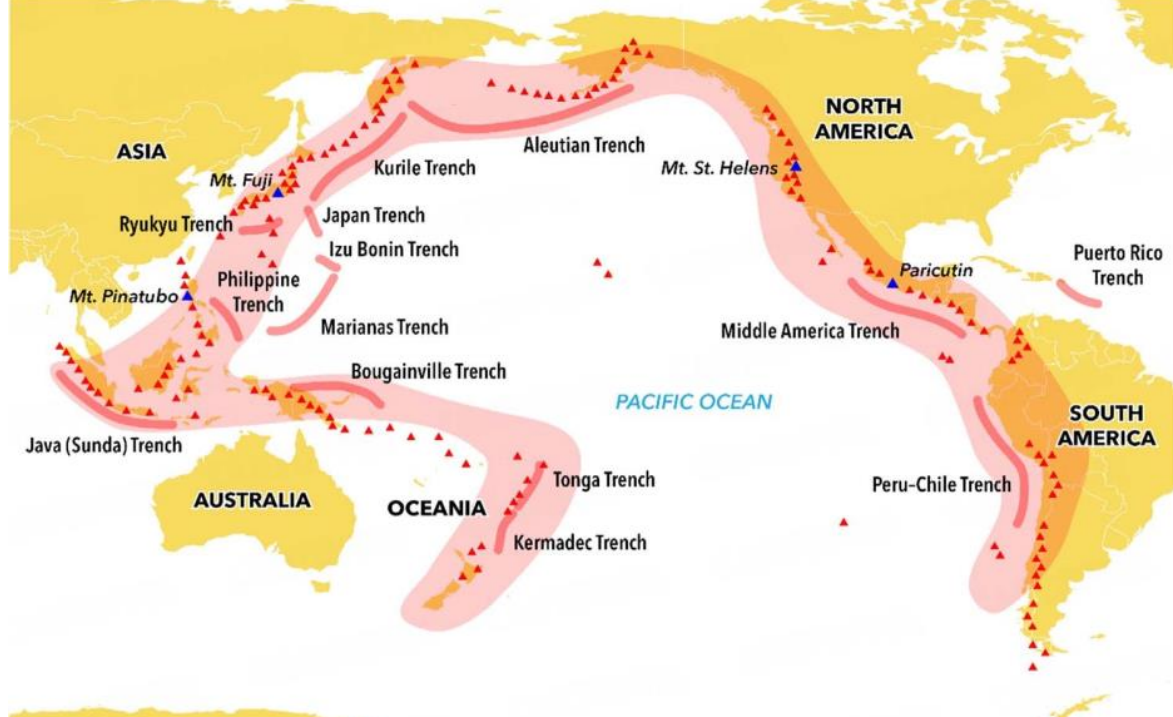

Figure 1. Ring of fire

Bencana yang berkaitan dengan tsunami seperti tsunami Samudra Hindia di Indonesia pada tahun 2004 dan tsunami Jepang di tahun 2011 menyebabkan banyak negara mengembangkan sistem peringatan dini dan rencana evakuasi, contohnya adalah pengembangan sistem peringatan dini tsunami di Samudra Hindia yang dikerjakan paska tsunami 2004 (Esteban et al., 2013). Indonesia memiliki paparan populasi tertinggi ketiga terhadap tsunami di Dunia, dengan perkiraan 5,5 juta orang berisiko terkena tsunami sekali dalam 500 tahun (Hamzah et al., 2000; Løvholt et al., 2014). Badan Meteorologi Klimatologi dan Geofisika mencatat setidaknya ada 28 gempa bumi yang berdampak tsunami di perairan Indonesia pada tahun 2000 hingga 2018. Tercatat beberapa diantaranya yaitu tsunami "raksasa" sumatra pada 26 Desember 2004 di Banda Aceh, Provinsi Nangro Aceh Darusalam (BMKG, 2018). Fakta tersebut cukup menggambarkan seberapa mengerikannya dampak jalur subduksi yang terdapat di Indonesia.

Di wilayah selatan Jawa, lokasi yang mungkin mampu menghasilkan tsunami besar dekat lapangan adalah bagian timur megathrust Sunda yang terdiri dari lempeng Indo-Australia yang menundukkan di bawah margin Eurasia yang utama (Mulia et al., 2019). Probabilitas tahunan untuk mengalami tsunami dengan ketinggian $>0,5 \mathrm{~m}$ di pantai lebih besar dari 10\% untuk Sumatera, Jawa, pulau Sunda (Bali, Lombok, Flores, Sumba) dan Papua utara (Horspool et al., 2014). Dengan demikian dapat disimpulkan bahwa Indonesia berada dalam ancaman tsunami "raksasa" atau megathrust di 
sepanjang pesisir selatan mulai dari Pulau Sumatra sampai dengan Kepulauan Nusa Tenggara.

Kabupaten Purworejo, Provinsi Jawa Tengah, Indonesia terletak di Pulau Jawa. Lokasinya berada di selatan dan berbatasan langsung dengan Samudera Hindia. Dengan demikian, Purworejo merupakan salah satu kabupaten yang terancam. Acaman tersebut semestinya menjadi perhatian agar penduduk Purworejo memiliki kesiapsiagaan kaitannya dengan bencana tsunami. Lebih khususnya pada penduduk yang berada di pesisir. Memperkuat kesiapsiagaan lokal dipandang sebagai elemen penting dalam respon dan pemulihan yang efektif (Levac et al., 2012). Kesiapsiagaan terpengaruh dengan kondisi keruangan, itu sebebnya kesiapsiagaan lokal dipandang penting. Contohnya yaitu adanya kearifan lokal, sejarah kejadian tsunami (sudah pernah terjadi atau belum), dsb.

Penelitian ini bertujuan untuk mengukur tingkat kesiapsiagaan masyarakat atau komunitas di pesisir Purworejo. Dengan mengetahui tingkat kesiapsiagaan, kedepannya dapat digunakan untuk pertimbangan saat merancang kebijakan atau perencanaan kebencanaan. Dengan adanya penelitian ini juga untuk menumbuhkan kesadaran di masyarakat atau pihak-pihak yang terkait dengan kebencanaan.

\section{METODE}

Penelitian ini meliputi 16 desa yang berada di sepanjang pesisir Kabupaten Purworejo Desa-desa tersebut terdapat di 3 kecamatan, yaitu kecamatan Grabag, Ngombol dan Purwodadi. Pemilihan lokasi tersebut karena memiliki ancaman tsunami yang paling tinggi di Purworejo. Hal tersebut berdasarkan peta pemodelan tsunami terbitan Pemerintah Kabupaten Purworejo yang berkerja sama dengan Pemerintah Jerman.

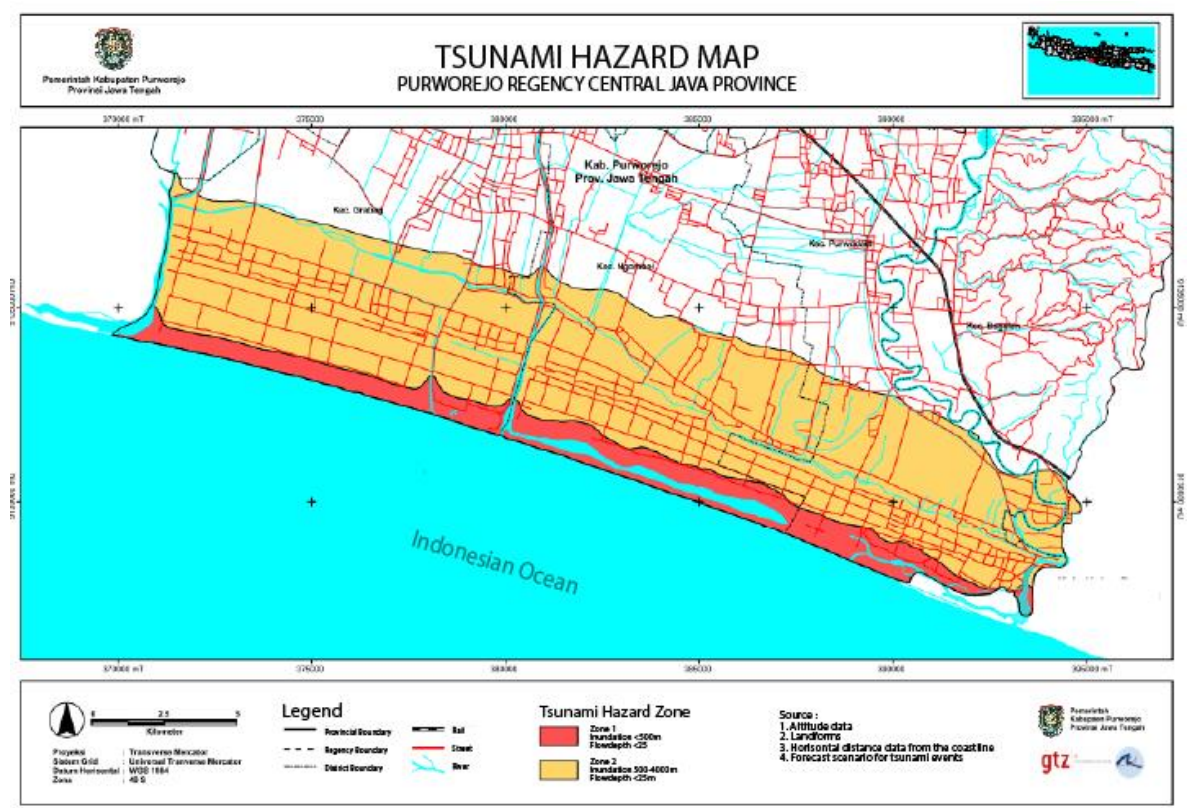

Figure 2. Tsunami Hazard Map

(Source : Gitewz.org)

Teknik pengumpulan data menggunakan kuisioner. Penentuan jumlah sampel menggunakan rumus slovin dengan populasi seluruh penduduk yang bertempat tinggal di desa-desa pesisir Purworejo. Dari rumus tersebut menghasilkan jumlah minimal sampel sabanyak 100 responden. Pengumpulan data juga ditambah dengan 
wawancara, observasi dan dokumentasi. Hal tersebut bertujuan untuk melakukan uji validitas serta untuk mengeksplorasi kajian lebih dalam.

Kuisioner berpedoman pada pedoman LIPI (2006) yang bersumber pada skor angket yang telah dibagikan kepada masing-masing responden. Penilaian menggunakan 5 indeks. Parameternya yaitu pengetahuan, kebijakan dan panduan, rencana tanggap darurat, peringatan bencana dan mobilisasi sumber daya.

Table 1. Kategori kesiapsiagaan

\begin{tabular}{c|cc}
\hline \multicolumn{3}{c}{ Indeks Total } \\
\hline $80-100 \%$ & Kesiapsiagaan Tinggi \\
$60-79 \%$ & Kesiapsiagaan Sedang \\
$>60 \%$ & Kesiapsiagaan Rendah
\end{tabular}

Sumber : LIPI \& UNESCO/ISDR (2006)

\section{HASIL DAN PEMBAHASAN}

Berdasarkan hasil kuisioner, wawancara, observasi, dan dokumentasi di lapangan mendapatkan hasil yang mendalam mengenai kajian di dalam penelitian ini. Dalam penelitian ini, indeks kesiapsiagaan terhadap bencana tsunami didapatkan dari individu pada masing-masing desa. Jumlah setiap individu yang dijadikan sebagai sampel pada tiap desa dibagi secara proporsional berdasarkan jumlah penduduk total dalam satu desa. Parameter yang digunakan dalam mengukur kesiapsiagaan masyarakat terhadap yaitu pengetahuan, kebijakan dan panduan, rencana tanggap darurat, peringatan bencana dan mobilisasi sumber daya. Adapun hasil dari perhitungan indeks kesiapsiagaan berdasarkan parameter tersebut setiap individu sebagai berikut :

\section{Pengetahuan}

Aspek yang diukur yaitu mencangkup pengertian bencana alam, kejadian yang dapat menakibatkan bencana, penyebab terjadinya gempa, karakteristik bencana dan konstruksi bangunan yang ideal serta perilaku atau tindakan ketika terjadi bencana. Pertanyaan tersebut berkenaan dengan bencana gempa. Untuk spesifik mengenai tsunami yaitu mengukur pengetahuan tentang penyebab dan tanda-tanda tsunami,bangunan yang cocok di daerah rawan tsunami dan tindakan yang dilakukan saat tanda-tanda tsunami terjadi. Adapun hasil dari pengukuran tersebut yaitu sebagai berikut :

Table 2. Indeks Pengetahuan

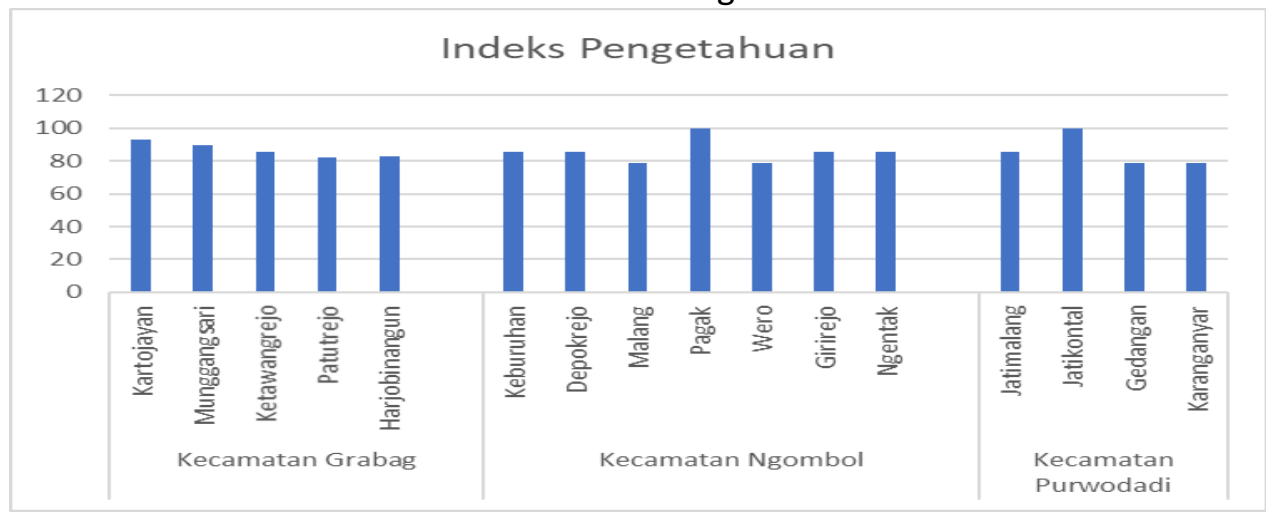


Berdasarkan hasil yang dapat kita lihat pada tabel Indeks pengetahuan di Kecamatan Grabag dengan 5 desa yang dijadikan sebagai sample menunjukkan hasil indeks pengetahuan berkisar antara 80-100, Desa Kartojayan memiliki indeks pengetahuan yang paling tinggi di Kecamatan Grabag. Kecamatan Ngombol dengan 7 desa sebagai sample hampir semua memiliki indeks pengetahuan yang rata berkisar di angka 80-an kecuali desa Pagak dengan indeks pengetahuan mencapai 100. Kecamatan Purwodadi dengan 4 desa sebagai sample memiliki indeks pengetahuan 80-100.

\section{Kebijakan dan Panduan}

Kajian kebijakan dan panduan meliputi pendidikan yang berkaitan dengan kesiapsiagaan bencana tsunami. Selain itu, peneliti juga melakukan kajian mengenai tindakan badan yang terkait kebencanaan. Berikut merupakan hasil dari indeks kebijakan dan panduan :

Table 3. Indeks Kebijakan dan Panduan

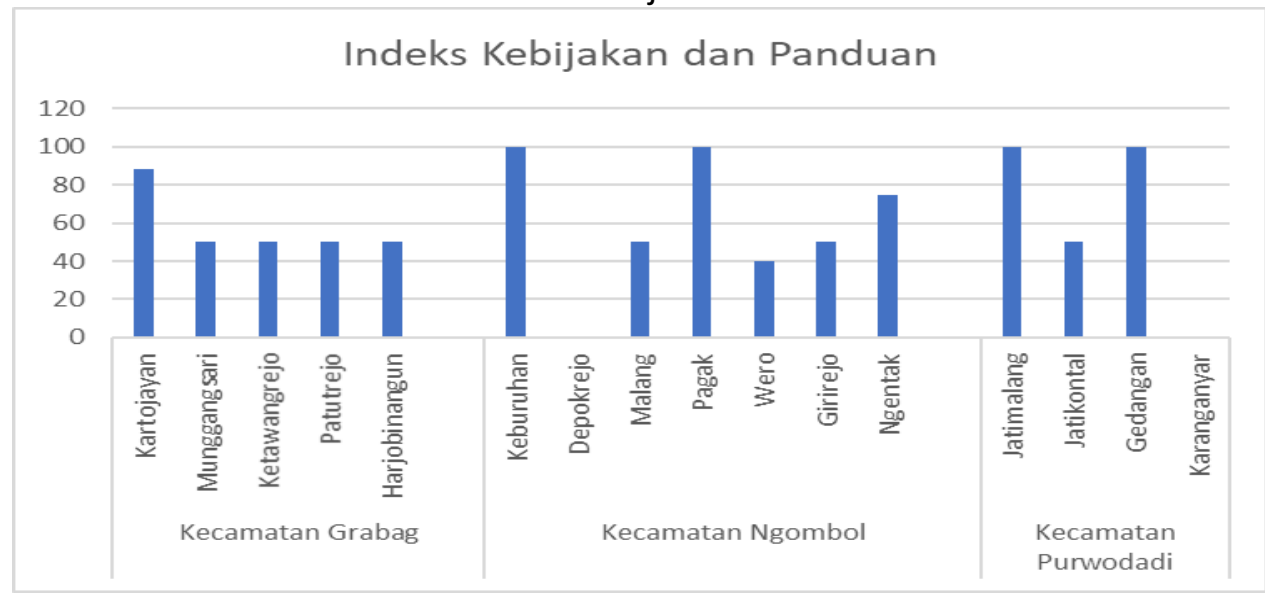

Hasil yang didapat berdasarkan tabel indeks kebijakan dan panduan di tiga kecamatan penelitian menunjukkan di Kecamatan Grabag yang memiliki indeks kebijakan dan panduan paling tinggi adalah desa Kartojayan. Kecamatan Ngombol yang memiliki indeks kebijakan dan panduan paling tinggi berada di Desa Keburuhan dan Desa Pagak. Di Kecamatan Grabag Desa Jatimalang dan Desa Gedangan memiliki indeks paling tinggi sedangkan Desa Karanganyar memiliki indeks paling rendah.

\section{Rencana Tanggap Darurat}

Rencana tanggap darurat yang dikaji adalah rencana yang terkait dengan evakuasi, pertolongan pertama dan penyelamatan untuk menekan jumlah kerugian korban jiwa. Meliputi tempat-tempat evakuasi, pemetaan, jalur evakuasi, kelengkapan dan kesediaan alat, demonstrasi dan prosedur tetapevakuasi. Hasil pengukuran rencana tanggap darurat menunjukan indeks sebagai berikut : 
Table 4. Indeks Rencana dan Tanggap Darurat

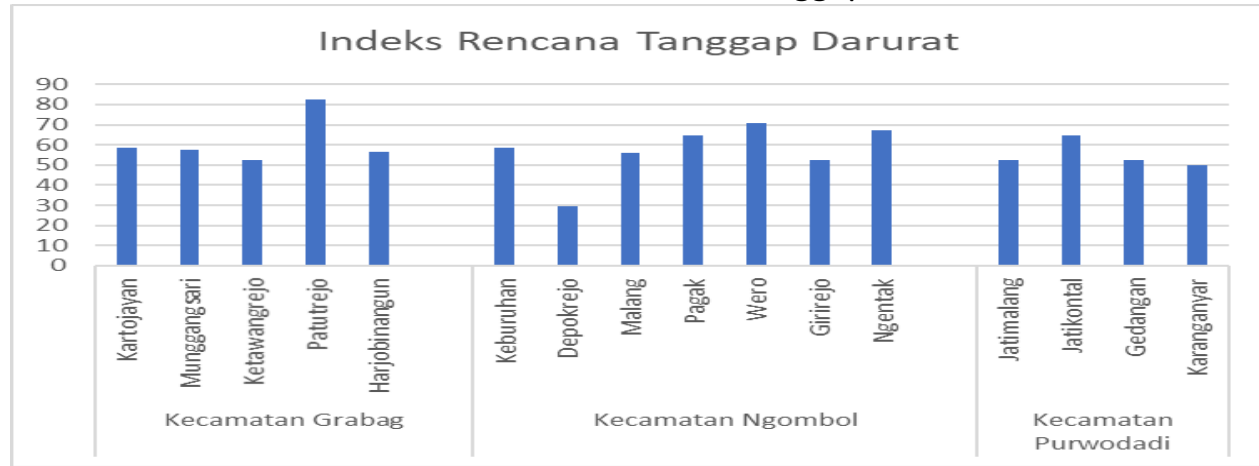

Hasil dalam tabel menunjukkan di Kecamatan Grabag memiliki indeks rencana dan tanggap darurat mengenai evakuasi, pertolongan pertama dan penyelamatan terhadap bencana paling tinggi berada di Desa Patutrejo. Kecamatan Ngombol desa-desa yang dijadikan sample memiliki indeks yang hampir sama rata, tetapi yang memiliki indeks paling tinggi berada di Desa Wero.

\section{Peringatan Dini}

Tanda peringatan dini dan persebaranya dikaji untuk menentukan indeks parameter ini. Hal tersebut dikarenakan dapat menekan jumlah korban atau meminimalisir korban. Demonstrasi juga dikaji dalam hal ini. Karena tanpa adanya demonstrasi, system peringatan dini tidak dapat optimal. Hasil indeks pengukuran parameter ini sebagai berikut :

Table 5. Indeks Sistem Peringatan

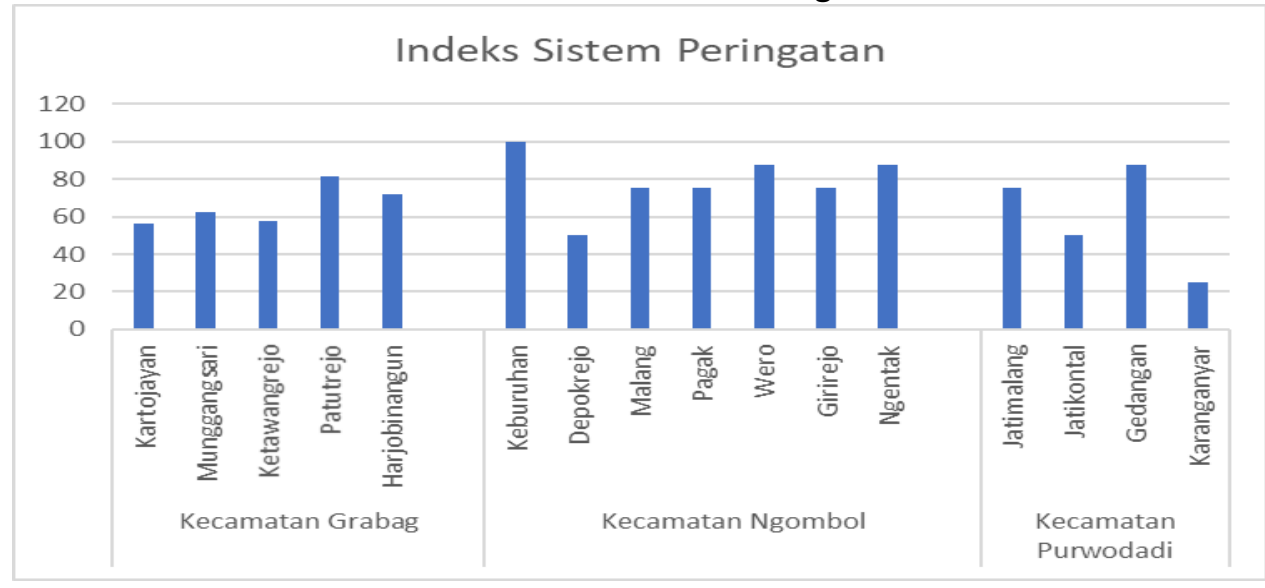

Berdasarkan hasil pada tabel diatas indeks sistem peringatan dini di Kecamatan Grabag wilayah yang memiliki sistim peringatan dini paling tinggi berada di desa Patutrejo. Di Kecamatan Ngombol yang memiliki indeks sistem peringatan dini paling tinggi di Desa Keburuhan. Di Kecamatan Purwodadi indeks sistem peringatan dini yang paling tinggi di Desa Gedangan.

\section{Mobilisasi Sumbe Daya}

Kemampuan untuk berpindah ke tempat yang lebih aman dikaji untuk menentukan indeks parameter ini. Sumberdaya yang dimaksud meliputi sumber daya manusia dan non manusia. Indeks dari mobilisasi sumber daya yaitu sebagai berikut : 
Table 6. Indeks Mobilisasi Sumber Daya

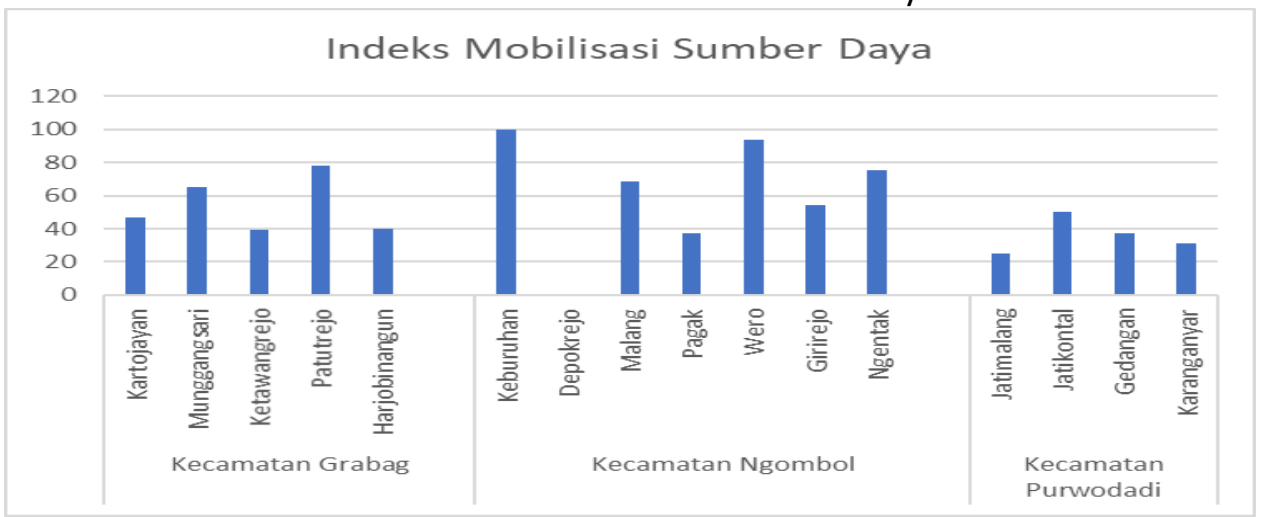

Tabel indeks mobilisasi sumber daya diatas menunjukkan di Kecamatan Grabag yang memiliki kemampuan mobilisasi paling tinggi yaitu berada di Desa Patutrejo, di Kecamatan Ngombol yaitu di Desa Keburuhan dan di Kecamatan Purwodadi yaitu di Desa Jatikontal. Dari ketiga kecamatan sampel di Kecamatan Purwodadi yang memiliki rata-rata paling rendah.

Grafik-grafik tersebut menunjukan indeks tiap parameter pada tiap desa. Dari indeks-indeks tersebut, kemudian digabungkan untuk mendapatkan indeks total kesiapsiagaan terhadap bencana tsunami. Indeks total kesiapsiagaan di pesisir Purworejo sebagai berikut :

Table 7. Indeks Total

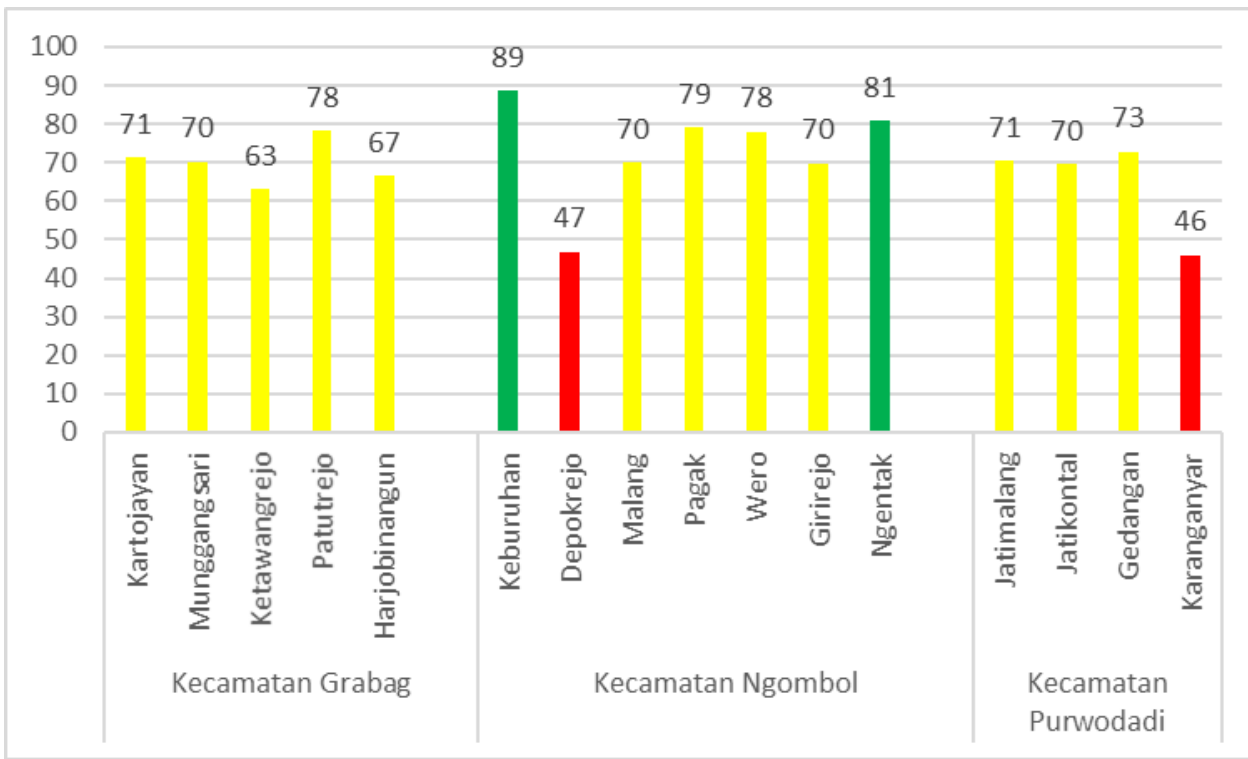

Pada grafik tersebut terdapat tiga warna batang. Kuning menunjukan tingkat kesiapsiagaan sedang, merah menunjukan rendah dan hijau menunjukan tinggi. Desa Depokrejo memiliki indeks yang rendah karena lokasinya yang memiliki aksesibilitas buruk. Indeks rendah juga terjadi di Desa Karanganyar. Hal tersebut memiliki korelasi dengan penduduknya yang tidak bermata pencaharian di pantai. Jatimalang menunjukan indeks tinggi, karena Ngentak memiliki wilayah yang sempit dan jumlah warga yang relaif sedikit. Hal tersebut memberi keuntungan untuk masyarakat lebih mudah dijangkau kaitannya dengan pembentukan kesiapsiagaan bencana tsunami. Kondisi geografis dan demorafis tersebut juga terdapat di desa Girirejo, Wero dan Pagak. Indeksnya juga meunjukann gap yang tidak terlalu jauh. Indeks tinggi juga terdapat di Desa Keburuhan. Lain halnya dengan sebelumnya, Keburuhan memiliki penduduk dua kali lipat lebih banyak dari desa-desa di Kecamatan Ngombol. Desa 
Keburuhan dinobatkan sebagai kampung keluarga berencana, hal tersebut meingindikasikan bahwa penduduknya sudah dapat menerima sosialisasi lebih baik dari desa lain. Kemudian selebihnya memiliki indeks yang sedang dengan rata-rata di atas 70 . Angka tersebut mendekata 80 sebagai ambang batas atas kategori sedang.

\section{SIMPULAN}

Dari 16 desa, 12 desa memiiki tingkat sedang, 2 tinggi dan 2 rendah. Hasil tersebut masih didominasi oleh tingkat sedang. Hal tersebut mengindikasikan masih diperlukannya upanya peningkatan kesiapsiagaan. Jika berkaca pada desa dengan indeks tertinggi yaitu Keburuhan, di desa tersebut sudah dapat mengefektifkan sosialisasi sebagai cara untuk menumbuhkan kesadaran dan pengetahuan mengenai kebencanaan khususnya tsunami. Hal tersebut dampat berdampak besar karena pendidikan dan demografi merupakan beberapa prediktor signifikan dari tingkat kesiapsiagaan bencana (Kim \& Kang, 2010).

Studi ini menyoroti perlunya kebijakan dan program intervensi yang efektif untuk meningkatkan kesiapsiagaan bencana tsunami. Individu yang memiliki hubungan baik dengan teman atau tetangga mereka dapat, bersama dengan organisasi masyarakat, membangun kapasitas untuk mempersiapkan diri secara efektif menghadapi tsunami. Oleh karena itu, pembuat kebijakan dan profesional layanan manusia harus melakukan upaya untuk mengidentifikasi, merekrut, dan membina hubungan dengan tokoh masyarakat. Para pemimpin komunitas ini dapat mencakup pengorganisasi komunitas, anggota dewan lokal dan pemimpin pemerintah lainnya, pemimpin nirlaba, relawan atau pemimpin agama, dan penduduk jangka Panjang.

\section{DAFTAR PUSTAKA}

Bahagia, N., Sandee, H., \& Meeuws, R. (2013). State of Logistics Indonesia 2013. http://www.panteia.eu/nl/News/2013/09/ /media/9

PanteiaEU/files/StateofLogisticsIndonesia2013.ashx

BMKG. (2018). Katalog Tsunami Indonesia Tahun 416-2017.

Esteban, M., Tsimopoulou, V., Mikami, T., Yun, N. Y., Suppasri, A., \& Shibayama, T. (2013). Recent tsunamis events and preparedness: Development of tsunami awareness in Indonesia, Chile and Japan. International Journal of Disaster Risk Reduction, 5, 84-97. https://doi.org/10.1016/j.ijdrr.2013.07.002

Hamzah, L., Puspito, N., \& Imamura, F. (2000). Tsunami Catalog Indonesia.pdf. In Journal of Natural Disaster Science (Vol. 22, Issue 1, pp. 25-43). https://www.jstage.jst.go.jp/article/jnds/22/1/22_1_25/_pdf

Horspool, N., Pranantyo, I., Griffin, J., Latief, H., Natawidjaja, D. H., Kongko, W., Cipta, A., Bustaman, B., Anugrah, S. D., \& Thio, H. K. (2014). A probabilistic tsunami hazard assessment for Indonesia. Natural Hazards and Earth System Sciences, 14(11), 3105-3122. https://doi.org/10.5194/nhess-14-3105-2014

Kim, Y. C., \& Kang, J. (2010). Communication, neighbourhood belonging and household hurricane preparedness. Disasters, 34(2), 470-488. https://doi.org/10.1111/j.1467-7717.2009.01138.x

Levac, J., Toal-Sullivan, D., \& O'Sullivan, T. L. (2012). Household emergency preparedness: A literature review. Journal of Community Health, 37(3), 725-733. https://doi.org/10.1007/s10900-011-9488-x

Løvholt, F., Glimsdal, S., Harbitz, C. B., Horspool, N., Smebye, H., de Bono, A., \& Nadim, F. (2014). Global tsunami hazard and exposure due to large co-seismic slip. International Journal of Disaster Risk Reduction, 10(PB), 406-418. https://doi.org/10.1016/j.jjdrr.2014.04.003

Mulia, I. E., Gusman, A. R., Williamson, A. L., \& Satake, K. (2019). An Optimized Array Configuration of Tsunami Observation Network Off Southern Java, Indonesia. In Journal of Geophysical Research: Solid Earth (Vol. 124, Issue 9). 
https://doi.org/10.1029/2019JB017600

Pambudi, N. A. (2018). Geothermal power generation in Indonesia, a country within the ring of fire: Current status, future development and policy. Renewable and Sustainable Energy Reviews, 81(March 2017), 2893-2901.

https://doi.org/10.1016/j.rser.2017.06.096 